\title{
Correction to: Systemic microvascular rarefaction is correlated with dysfunction of late endothelial progenitor cells in mild hypertension: a substudy of EXCAVATION-CHN1
}

Jianwen Liang ${ }^{1,2+}$, Yan $\mathrm{Li}^{1 \dagger}$, Long Chen ${ }^{1}$, Wenhao Xia ${ }^{1}$, Guifu Wu${ }^{2}$, Xinzhu Tong ${ }^{1}$, Chen Su', Jiang He' Xiufang $\operatorname{Lin}^{3^{*}}$ and Jun TaO ${ }^{1,4^{*}}$

\section{Correction to: J Transl Med (2019) 17:368} https://doi.org/10.1186/s12967-019-2108-8

Upon publication of the original article [1], it was noticed that Jun Tao's affiliation information is not complete. The full affiliation information for Jun Tao can be found below and in the complete affiliation list of this Correction article.

- Department of Hypertension and Vascular Disease, The First Affiliated Hospital, Sun Yat-Sen University, Guangzhou 510080, China.

- Key Laboratory on Assisted Circulation, Ministry of Health, Guangzhou 510080, China.
University, Zhuhai 519000, China. ${ }^{4}$ Key Laboratory on Assisted Circulation, Ministry of Health, Guangzhou 510080, China.

Published online: 16 January 2020

Reference

1. Liang J, Li Y, Chen L, Xia W, Wu G, Tong X, Su C, He J, Lin X, Tao J. Systemic microvascular rarefaction is correlated with dysfunction of late endothelial progenitor cells in mild hypertension: a substudy of EXCAVATION-CHN1. J TransI Med. 2019;17:368. https://doi.org/10.1186/ s12967-019-2108-8.

\section{Publisher's Note}

Springer Nature remains neutral with regard to jurisdictional claims in published maps and institutional affiliations.

\section{Author details}

${ }^{1}$ Department of Hypertension and Vascular Disease, The First Affiliated Hospital, Sun Yat-Sen University, Guangzhou 510080, China. ${ }^{2}$ Department of Cardiology, The Eighth Affiliated Hospital, Sun Yat-Sen University, Shenzhen,

China. ${ }^{3}$ Department of Cardiology, The Fifth Affiliated Hospital, Sun Yat-Sen

Full list of author information is available at the end of the article

\section{$\triangle B M C$}

(c) The Author(s) 2020. This article is licensed under a Creative Commons Attribution 4.0 International License, which permits use, sharing, adaptation, distribution and reproduction in any medium or format, as long as you give appropriate credit to the original author(s) and the source, provide a link to the Creative Commons licence, and indicate if changes were made. The images or other third party material in this article are included in the article's Creative Commons licence, unless indicated otherwise in a credit line to the material. If material is not included in the article's Creative Commons licence and your intended use is not permitted by statutory regulation or exceeds the permitted use, you will need to obtain permission directly from the copyright holder. To view a copy of this licence, visit http://creativecommons.org/licenses/by/4.0/. The Creative Commons Public Domain Dedication waiver (http://creativecommons.org/publicdomain/zero/1.0/) applies to the data made available in this article, unless otherwise stated in a credit line to the data. 